\title{
Strategies for the Identification of Novel Brain Specific Genes Affected in Alzheimer Disease
}

\author{
D.G. Walker, B.E. Boyes, P.L. McGeer and E.G. McGeer
}

\begin{abstract}
The pathological changes that occur in Alzheimer disease (AD) brain lead to a large loss of various classes of neurons and the production of novel proteinaceous elements such as neuritic plaques and neurofibrillary tangles. For the neuronal loss to occur and these elements to arise, there must be a disturbance in the expression or regulation of genes that code for proteins required for normal cell maintenance, or perhaps even for the expression of genes unique to $\mathrm{AD}$. We describe the construction of a cDNA library from the human substantia innominata and strategies for isolating genes that are expressed differentially between brain regions and which may be affected by AD. Some of the results obtained using these strategies and a preliminary description of a novel brain specific mRNA of $15.5 \mathrm{~kb}$, whose expression is increased in $\mathrm{AD}$ affected temporal cortex, are presented.

RÉSUMÉ: Génétique moléculaire de la maladie d'Alzheimer familiale Les changements pathologiques qui surviennent dans le cerveau de patients atteints de la maladie d'Alzheimer (MA) provoquent une perte considérable de neurones de différentes classes et une production d'éléments protéiques nouveaux, dont les plaques névritiques et les amas neurofibrillaires. Pour que cette perte neuronale puisse survenir et que ces éléments apparaissent, il doit exister une perturbation de l'expression ou de la régulation des gènes qui codent pour les protéines nécessaires au maintien de la cellule normale, ou peut-être même à l'expression de gènes uniques à la MA. Nous décrivons la construction d'une librairie d'ADN complémentaire à partir de la substance innominée humaine et les stratégies pour isoler les gènes qui sont exprimés de façon différentielle entre les régions du cerveau, gènes qui pourraient être atteints dans la MA. Nous présentons quelques uns des résultats obtenus en utilisant ces stratégies ainsi qu'une description préliminarie d'un nouveau ARN messager de $15.5 \mathrm{~kb}$, spécifique au cerveau, dont l'expression est augmentée dans le cortex temporal de patients atteints de la MA.
\end{abstract}

Can. J. Neurol.Sci. 1989; 16:483-489

Alzheimer disease (AD) is a neurodegenerative disease of the elderly that is characterized by a severe loss of cognitive function. To date, little is known about the cause of the neurodegeneration that occurs in AD. Hallmark pathological features of $A D$ are the loss of neurons together with the formation of neurofibrillary tangles (NFT) and amyloid containing neuritic plaques (NP). The application of basic scientific methodologies to $A D$ research has concentrated on elucidating the nature and etiology of these abnormal proteinaceous structures. ${ }^{1}$ The plaques and tangles are most abundant in the temporal cortex, parietal cortex and hippocampus and occur to a lesser extent in the frontal cortex and basal forebrain. There is now substantial evidence indicating selective vulnerability of certain neuronal groups. For example, the magnocellular cholinergic neurons of the basal forebrain are particularly vulnerable in AD. ${ }^{2}$ This is reflected by a decrease in the specific activity of neocortical choline acetyltransferase (ChAT), the enzyme responsible for the synthesis of acetylcholine. Although a number of other neuronal systems are selectively affected, e.g. noradrenergic neurons of the locus coeruleus, serotonergic neurons of the raphe complex, neurons of the central and medial nuclei of the amygdala, hippocampal pyramidal neurons, and neocortical glutamatergic pyramidal neurons, neocortical ChAT levels remain one of the most reliable diagnostic criteria for AD. ${ }^{3}$ The molecular events that lead to the deposition of amyloid and the formation of neuritic plaques, the degeneration of neurons into insoluble paired helical filament containing tangles, and the selective loss of certain neuronal populations are the main identified areas of $\mathrm{AD}$ research. It can be assumed that these molecular events are accompanied by an alteration in the normal expression of the genes that are necessary for maintaining normal cell function at one of the levels of gene regulation, i.e. RNA transcription, RNA stability, RNA translation or post-translational modifications of proteins. ${ }^{4} \mathrm{We}$, and other research groups, are using this

From the Kinsmen Laboratory of Neurological Research, Department of Psychiatry, University of British Columbia, Vancouver 
assumption to apply recombinant DNA methodology to the investigation of gene expression in $\mathrm{AD}$ affected brains. There are two methods of approach: a) the analysis of levels of expression of identified genes, and b) the identification and analysis of unidentified genes which show differential expression between normal and $A D$ affected brains. In this paper, we provide some review information on these approaches and some of our experimental findings using the second approach.

\section{Examination of the Expression of Identified Genes in AD Brains}

Measurements of the expression of identified genes in various regions of $A D$ affected brains have been the object of a number of investigations, in attempts to identify key genetic alterations in $\mathrm{AD}$. The majority of these studies have been with various probes derived from the sequence of the amyloid precursor protein (APP) gene. It has been suggested that abnormal expression of this gene may be the cause of $B$-amyloid protein deposition in senile plaques. Several groups have used synthetic oligonucleotide probes, designed from the amino acid sequence obtained by Glenner and Wong from extracted vascular amyloid, ${ }^{5}$ to isolate cDNA copies of the gene for the amyloid precursor protein..$^{6-9}$ It was found that this gene was widely expressed in a number of tissues besides brain ${ }^{6-9}$ and was highly homologous to genes present in species that do not develop amyloid containing plaques with age. ${ }^{10,11}$ It was subsequently shown that alternate forms of the originally identified APP gene existed that contained 56 and 75 extra amino acids. The extra 56 amino acids showed about $50 \%$ homology to the Kunitz type serine protease inhibitor. ${ }^{12-14}$ The third form has an extra 19 amino acids added to this domain. The three forms of APP mRNA are referred to as APP695, APP751 and APP770. The APP695 form is more highly expressed in nervous tissue, particularly neurons, while the insert containing forms occur widely in neural and non-neural tissues. With the complete cDNA probe, Northern blot hybridization analyses showed a decrease in the expression of APP in AD affected temporal or frontal cortex compared to tissue from non-demented cases. 15,16 With probes specific for the APP695, APP751 and APP770 forms, Northern blot hybridizations of RNAs from cortex of $A D$ and normal cases revealed an increase in AD in the APP770 transcript with no change in the expression of APP695 and APP751. ${ }^{17}$ However, in another study, a $65 \%$ decrease in the expression of the APP695 transcript was found in AD cortex compared to cortex from neurologically normal cases with no change being found in the levels of the APP75I transcript.18 Quantitative in situ hybridization studies have shown an apparent increase in APP gene expression in magnocellular neurons of the nucleus basalis of Meynert in AD, 19 due to increased expression of the APP695 transcript. ${ }^{20}$ An alteration in the expression of the APP gene in the parasubiculum neurons of the hippocampus in AD has also been observed.21 The relevance of APP gene expression to the pathology of AD is still unclear, as there is no clear difference in the expression in brain regions or neuronal cell types that are not affected in AD (e.g. hypothalamus) compared to those that are affected in AD (e.g. temporal cortex). ${ }^{15}$ Futhermore, DNA sequence analysis has shown that there is no difference between the APP gene of neurologically normal and $A D$ affected individuals. 15,22 This would seem to indicate that the AD brain amyloid protein is not a mutated form of the normal one, and that the deposition in plaques may occur due to abnormal processing of the normal APP. The initial interest in the APP gene was heightened by its localization to chromosome 21 . The gene was thought at first to be in the vicinity of a DNA probe that identified a genetic defect for some families with AD. ${ }^{23}$ Subsequent work has shown that recombination events occur between the FAD locus detected by this probe and the APP gene sufficient to establish that they are separated by more than eight million base pairs. ${ }^{24}$ There is no evidence of gene duplication of the APP gene in the majority of AD affected individuals. 25

The genes of some of the proteins found to be associated with neurofibrillary tangles (NFT) have been identified (tau, microtubule associated protein 2 (MAP 2), neurofilament complex components, ubiquitin). The expression of the microtubule associated protein tau gene was shown not to be different in $A D$ affected tissue. ${ }^{26}$ Significant decreases in the expression of one of the genes of the neurofilament complex, the neurofilament $\mathrm{L}$ gene, were observed in AD. ${ }^{16,27}$ It is unclear whether this decrease results from overall loss of neurons expressing this gene or is occurring as an earlier event that may be contributing to the degeneration of affected neurons. Increases in levels of glial fibrillary acidic protein (GFAP) mRNA, a specific marker for astrocytes, have also been observed in AD affected brains, but this is probably a result of reactive astrocytosis. ${ }^{27,28}$

Indications that significant data may be obtained on pathological mechanisms of AD by the study of neuronal growth and regulatory factors have come from studies of expression of genes of nerve growth factor (NGF) and its receptor. It was shown that there was no significant difference in levels of NGF mRNA expression in cortex of normal and AD cases. ${ }^{29}$ Nerve growth factor appears to have a role in the development and survival of central cholinergic neurons. ${ }^{30}$ Treatment with this agent can prevent the degeneration of lesioned cholinergic neurons in rats. ${ }^{31}$ NGF appears to function as a retrograde trophic messenger for basal forebrain cholinergic neurons. Similarly, it was shown that there was no difference in the levels of expression of NGF receptor mRNA in the human basal forebrain between normal and $\mathrm{AD}$ cases. ${ }^{32}$ As the loss of magnocellular neurons from this brain region is well documented, 2,33,34 it would appear that the surviving neurons are expressing increased levels of NGF receptor mRNA. The degeneration of these neurons may be occurring as a result of the interruption of the retrograde supply of NGF.

\section{Analysis of the Expression of Unidentified Genes in AD}

Although there is obviously great value in analysing the expression of key marker genes whose protein products have been characterized, these genes represent only a small fraction of those expressed specifically in human brain. ${ }^{35}$ The genes studied as possibly being related to neuronal degeneration have been those of high abundance neuronal structural elements. The techniques of differential/subtractive hybridization offer the possibility of directly identifying genes whose expression is increased or decreased in $\mathrm{AD}$, even though the proteins these genes are coding for remain unknown. This methodology has been widely applied to the study of gene expression in developing tissues, especially the brain, ${ }^{36}$ and in characterizing genes expressed in mutant strains of animals. ${ }^{37}$ These techniques have allowed the identification of anonymous genes whose expres- 
sion is increased or decreased between two populations of RNA. However, several factors must be considered in applying these techniques to neurodegenerative diseases. The AD brain has a large neuronal loss with associated hypertrophy of astrocytes. The use of differential/subtractive screening techniques to compare genes expressed in AD affected brain tissue with those expressed in normal brain will primarily identify abundant astrocyte genes. A considerable amount of secondary screening of differentially expressed genes, along with careful interpretation, may be required to identify those genes whose induction is not secondary to the degenerative process. For example, subtractive hybridization of scrapie infected brain cDNA from normal hamster brain identified three such genes: GFAP, metallothionein II and the B chain of $\alpha$-crystallin, all of which are considered to be nonspecific markers of neurodegeneration. ${ }^{38}$ However, the approach of differential hybridization has been successfully applied by May and colleagues ${ }^{39}$ to isolate a neuronal gene whose expression is increased in $A D$ affected hippocampus.

\section{Analysis of Gene Expression in Human Substantia Innominata}

The aim of the project we have undertaken is to investigate the molecular biology of the neurons present within the substantia innominata (SI), an area highly enriched in magnocellular cholinergic neurons, and the effect of $\mathrm{AD}$ on genes expressed in this region. For these studies using postmortem human brain tissue, total cellular RNA was prepared by the method of Chirgwin. 40 This method has been used to prepare relatively intact RNA from frozen tissue, as assessed by its limited extent of degradation, and its ability to be an efficient substrate for reverse transcription and in vitro translation. The extent of degradation in any sample is judged by the relative intensities of the $28 \mathrm{~S}$ and $18 \mathrm{~S}$ ribosomal bands, when samples are separated by formaldehyde agarose gel electrophoresis and stained with ethidium bromide, and by the intactness of hybridization signals on Northern blots using probes for the APP and glutamic acid decarboxylase genes. These probes detect major mRNA bands of 3.5 and $3.7 \mathrm{~kb}$, respectively. In our experience, the intactness of these signals gives a more reliable estimation of degradation than does the use of an actin probe (which detects an mRNA of $1.8 \mathrm{~kb}$ ). Relative yields of total cellular RNA from hippocampus, temporal cortex and SI of AD and neurologically normal cases are shown in Figure 1. There was no significant difference between yields of RNA from temporal cortex and SI of AD and normal cases. However, a significant decrease in RNA yield from hippocampus of $\mathrm{AD}$ was observed.

\section{cDNA Library Construction and Screening Methodology}

Using mRNA from the SI of two neurologically normal cases (ages 79 and 80 years), a cDNA library was constructed. Poly $\mathrm{A}^{+}$RNA was prepared by batch absorption to and elution from oligo dT cellulose. Double stranded cDNA was prepared by the method of Gubler and Hoffman. ${ }^{41}$ After the addition of EcoRI adaptors, the cDNA was ligated to EcoRI cleaved plasmid vector pT7T318U. This was used to tranform E.Coli (strain DH5 $\alpha$ ) to ampicillin resistance using the technique of electroporation. ${ }^{42}$ A library of about one million independent clones was produced. Fifty thousand primary clones were plated out onto nitrocellulose membranes for screening, while the rest were amplified and frozen.

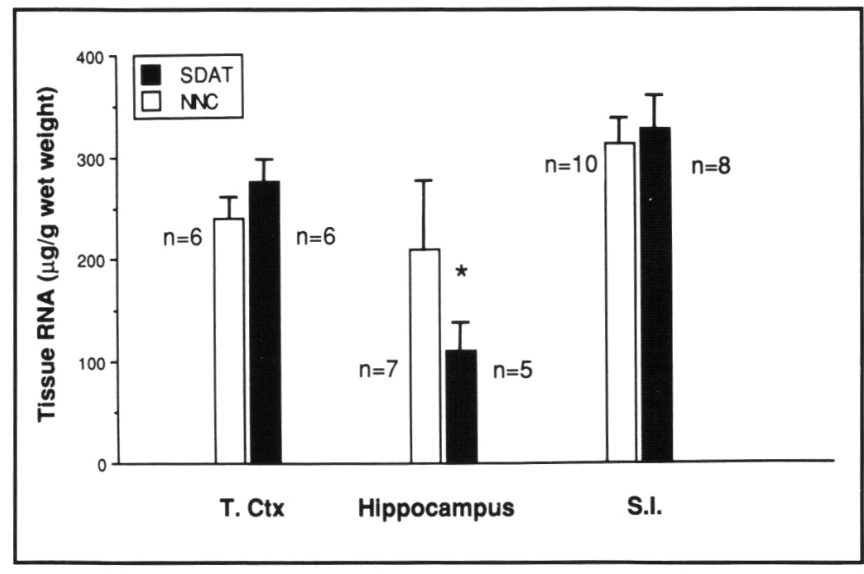

Figure I - Relative yields of total cellular RNA ( $\mu \mathrm{g}$ RNA/gram wet weight of tissue) extracted from temporal cortex, hippocampus and substantia innominata of neurologically normal control (NNC) and Alzheimer disease (SDAT) affected cases. * statistically significant difference $p<0.05$. $n$, number of cases of each group examined.

As the amount of RNA available from the human SI is limited ( $1-2 \mu \mathrm{g}$ poly $\left.\mathrm{A}^{+} / \mathrm{case}\right)$, large scale differential hybridization or subtractive hybridization procedures were not feasible. In order to identify regionally expressed genes, a negative screening protocol was adopted that would allow the removal of genes expressed in a brain region that did not contain the cells of interest. This procedure was similar to that used to identify cholinergic specific genes of the Torpedo ray. 43 The library was first screened by colony hybridization using a cDNA probe made from cerebellar RNA. The rationale is that the cerebellum is only marginally affected by the degenerative changes of $A D$, and furthermore contains no cell bodies of cholinergic neurons. In addition, it was assumed that this procedure would detect (and thus exclude) any abundant astrocytic genes, whose expression is likely to be increased during gliotic changes in AD (eg GFAP). This screening procedure (summarized in Figure 2) should allow the identification of neuronal genes whose expression is increased in, or restricted to, the SI, although differential hybridization will not be able to detect genes of less than $0.06 \%$ abundance. ${ }^{44}$ In addition, due to the higher content of white matter in the SI compared to the cerebellum, 45 oligodendrocytic genes will also be detected by this screening method. Clones that did not react with cDNA probes of cerebellar RNA ( $8 \%$ of initial numbers) were replated in a gridded array on membranes and rescreened with higher cerebellum probe input, to increase the sensitivity of the assay. This removed a further $75 \%$ of the clones, leaving $2 \%$ of the initial number. Plasmid DNAs were prepared from these clones and equivalent amounts were immobilized onto replicate membranes. These membranes were hybridized with cDNA probes prepared from normal SI RNA, AD SI RNA, cerebellum RNA, liver RNA, placenta RNA or corpus callosum RNA. It was apparent from the slot hybridizations that there were no moderate abundance genes detectable that were enriched in the SI (Figure 3). Fourteen clones were selected that gave differential signals between SI and cerebellum and no detectable signal with liver or corpus callosum RNA. Subsequent Northern blot hybridizations were performed on these to determine brain specificity and regional expression (Table 1, part A). The limited sensitivity of cDNA probes for 


CDNA LIBRARY FROM NORMAL S.I. POLY(A)+ RNA
NEGATIVE COLONY HYBRIDIZATION: CEREBELLUM
CDNA PROBE (LOW PROBE CONCENTRATION). SELECT
NEGATIVE CLONES
NEGATIVE COLONY HYBRIDIZATION: HYBRIDIZED WITH
CEREBELLUM CDNA PROBE (HIGH PROBE CONCENTRATION).
SELECT NEGATIVE CLONES
DIFFERENTIAL SLOT BLOT HYBRIDIZATIONS:PLASMID DNAS
HYBRIDIZED WITH CDNA PROBES FROM NORMAL SI RNA, AD SI
RNA, CEREBELLUM RNA, CORPUS CALLOSUM RNA, LIVER RNA,
PLACENTA RNA. SELECT CLONES WITH DIFFERENTIALLY
INCREASED SIGNALS WITH SI PROBES.
NORTHERN HYBRIDIZATIONS: RNA SAMPLES OF DIFFERENT
BRAIN REGIONS, LIVER AND PLACENTA PROBED WITH LABELLED
INSERTS OF SELECTED CLONES

Figure 2 - Summary of the first strategy used to select cDNA clones from SI CDNA library.

hybridization detection of clones of low abundance genes was evident as all, except one of the selected clones that detected transcripts by Northern hybridization, were found to be detectable in cerebellum RNA and $8 / 11$ of these were detectable in liver RNA. Clone pSI3a-64 only produced a hybridization signal with SI RNA. This signal was of very low intensity and formed a smear, rather than identifying a distinct band. Such a result is consistent with the presence of repetitive DNA

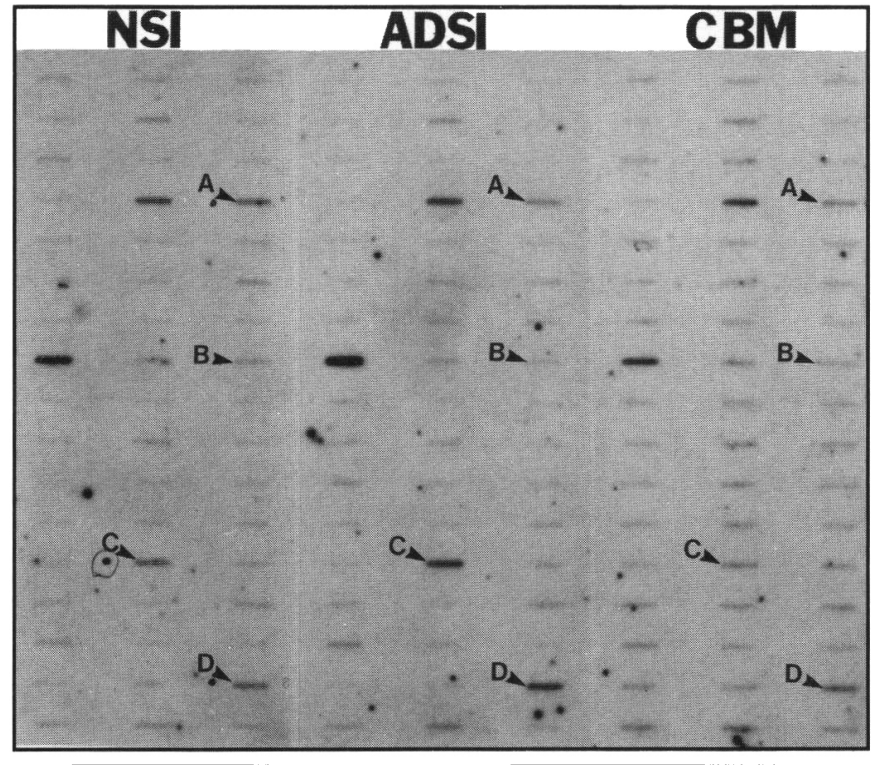

Figure 3 - Differential slot blot hybridization. Plasmid DNA was prepared from selected clones and $200 \mathrm{ng}$ of each sample was immobilized at each slot on Genescreen plus membranes. Replicas of each membrane were prepared. Membranes were hybridized separately with $32 P$ labelled probes prepared from normal SI cDNA (NSI), Alzheimer disease SI cDNA (ADSI) and cerebellum cDNA (CBM) by random priming. The letters indicate the following clones that are described in Table I (part A); A-pSI3a-24, B-pSI3a-36, C-pSI3a-50, D.pSI3a-60.

sequences within the cDNA. This clone is being investigated further. The low abundance of regional specific clones is in line with the results of Travis et al.46 They screened a monkey cortex library by subtractive hybridization and identified 5 clones out

Table 1: Detection of RNAs by Selected Clones

\begin{tabular}{|c|c|c|c|c|c|c|}
\hline Clone Number & Insert size (kbp) & Cbm & $\begin{array}{l}\text { Signal detection } \\
\text { Liver }\end{array}$ & Placenta & SI & Transcript \\
\hline \multicolumn{7}{|l|}{ A. } \\
\hline pSI3a-9 & 1.9 & + & - & - & + & $2100(\mathrm{WM}+)$ \\
\hline pSI3a-24 & 1.7 & $+t$ & ++ & ++ & nd & 1320 \\
\hline pSI $3 a-30$ & 1.2 & + & + & $+t$ & nd & 1900 \\
\hline pSI3a-36 & 0.8 & $+t$ & - & + & + & 4100 \\
\hline pSI3a-50 & 1.3 & ++ & + & + & nd & 1600 \\
\hline pSI3a-60 & 1.8 & $+1-$ & $+/-$ & $+1-$ & nd & smear \\
\hline $\mathrm{pSI} 3 \mathrm{a}-64$ & 1.6 & - & - & - & $+1-$ & smear \\
\hline pSI3a-99 & 2.1 & - & - & - & - & no band \\
\hline pSI3a-156 & 1.9 & - & - & - & nd & no band \\
\hline pSI3a-164 & 0.6 & + & + & + & nd & 950,2150 \\
\hline pSI3a-182 & 0.8 & - & - & - & - & no band \\
\hline pSI3a-190 & 2.0 & $+1-$ & + & + & nd & 2240 \\
\hline pSI3a-197 & 1.1 & + & + & ++ & + & $1600(\mathrm{WM}+)$ \\
\hline pSI3a-203 & 0.9 & ++ & $+t$ & + & + & $4300(\mathrm{WM}+)$ \\
\hline \multicolumn{7}{|l|}{ B. } \\
\hline pSI3ac-2 & 0.8 & + & - & + & ++ & 1500 (WM+) \\
\hline pSI3ac-7 & 1.4 & ++ & + & nd & ++ & 4800 \\
\hline pSI3ac- 16 & 0.6 & ++ & + & + & ++ & 5 bands \\
\hline pSI3ac-18 & 1.0 & + & $+1-$ & nd & + & 3300 (WM+) \\
\hline pSI3ac-22 & 0.8 & ++ & ++ & nd & ++ & $1400(\mathrm{WM}+)$ \\
\hline pSI3ac-24 & 3.0 & + & - & - & + & 15500 \\
\hline
\end{tabular}

- not detectable, +/- weak signal, + signal, ++ stronger signal, nd not determined, cbm cerebellum, SI substantia innominata, WM white matter

Transcript size estimated (bases RNA) relative to migration of B.R.L. RNA ladder. 

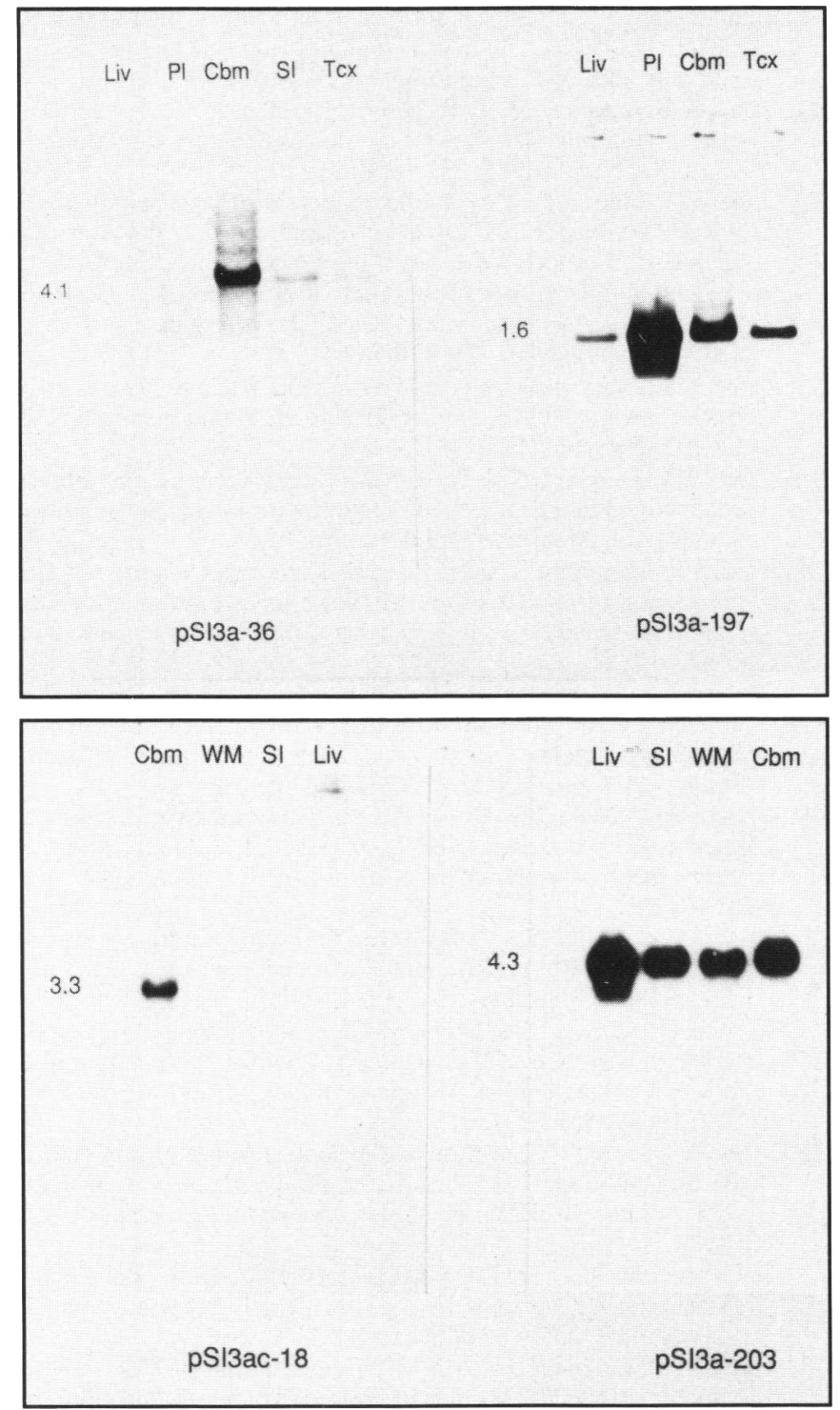

Figure 4-Northern hybridization analysis of representative clones to demonstrate distribution of expression. Cloned inserts were purified from vector DNA and labelled with $32 P$ by random priming. These were hybridized to $2 \mu g$ poly $A+R N A$, extracted from the indicated brain regions and tissues, which had been separated by gel electrophoresis and transferred to Genescreen plus membrane. Liv, liver: Pl, placenta: Cbm, cerebellum: WM, white matter: SI, substantia innominata: Tcx, temporal cortex. Numbers to left of autora. diograms designate estimated molecular size (kilobases of RNA).

of 25,000 that were specific for the cortex and not present in the cerebellum. These clones all turned out to be independent isolates of the same gene. Figure 4 shows representative Northern hybridizations of 4 clones identified by our negative screening protocol.

As the negative screening protocol described did not lead to the identification of any clones that clearly recognized SI specific genes, and as all the clones identified were of low abundance, a modification to the screening protocol was adopted (Figure 5). Clones that failed to give a hybridization signal with cerebellar cDNA probes were picked and regrown on replica membranes. The membranes were hybridized with cDNA probes made from

\section{CDNA LIBAARY FROM NORMAL SI POLY(A)+ RNA

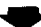 \\ NEGATIVE COLONY HYBRIDIZATION: CEREBELLUM CDNA PROBE (LOW PROBE CONCENTRATION). SELECT NEGATIVE CLONES}

\section{DIFFERENTIAL COLONY HYBRIDIZATION: HYBRIDIZED WITH} CDNA PROBES FROM NORMAL SI RNA, AD SI RNA, CEREBELLUM RNA, CORPUS CALLOSUM RNA AND LIVER RNA. SELECT CLONES WITH DIFFERENTIALLY INCREASED SIGNAL WITH SI PROBES. C

DIFFERENTIAL SOUTHERN BLOT HYBRIDIZATIONS:PLASMID DNAS HYBRIDIZEO WITH CDNA PROBES FROM NORMAL SI RNA, AD SI RNA, CEREBELLUM RNA, CORPUS CALLOSUM RNA AND LIVER RNA. SELECT CLONES WITH DIFFERENTIALLY INCREASED SIGNALS WITH SI PROBES.

NORTHERN HYBRIDIZATIONS: RNA SAMPLES OF DIFFERENT BRAIN REGIONS, LIVER AND PLACENTA PROBED WITH LABELLED INSERTS OF SELECTED CLONES.

Figure 5 - Summary of second strategy used 10 select CDNA clones from SI CDNA library.

normal SI RNA, AD SI RNA, cerebellum RNA, liver RNA, corpus callosum RNA and placenta RNA. Plasmid DNAs were isolated from selected clones which gave a differential hybridization signal by this procedure. These were digested with Eco Rl restriction endonuclease and the cDNA inserts separated from the vector by gel electrophoresis. The DNA samples were transferred to hybridization membranes and the replicate filters were hybridized with cDNA probes made from normal SI RNA, AD SI RNA, cerebellum RNA, liver RNA, corpus callosum RNA and placenta RNA. ${ }^{36}$ This modified screening procedure allowed the selection of clones that, although expressed in cerebellum, were differentially expressed in the SI. A summary of Northern hybridization data of clones selected by this alternate method is given in Table 1, part B. One clone (pSI3ac-24) containing a $3 \mathrm{~kb}$ insert, which was identified by the above described screening procedure, was selected for further characterization. The detailed characterization of this clone will be published elsewhere (manuscript in preparation, Boyes et al). This clone identified a mRNA of $15.5 \mathrm{~kb}$ that was detectable by Northern hybridization at different abundances in various brain regions and was not detectable in placenta or liver RNA samples. Attempts were made to quantify the relative levels of this gene in RNA extracted from the SI and temporal cortex of a number of $\mathrm{AD}$ and neurologically normal control cases, by Northern hybridization analyses. However, the intactness of the $15.5 \mathrm{~kb}$ band varied from case to case. In addition, because of its large size, a certain amount of degradation was always observed. As this degradation was inconsistent, quantification by Northern hybridization and gel autoradiograph densitometry appeared to be unreliable and a nuclease protection assay was used instead.47 This assay showed that this mRNA was detectable at a $30 \%$ higher level in AD temporal cortex RNA compared to normal cortex RNA, but at the same level in AD SI 
RNA compared to normal SI RNA. In addition this gene was present in 4-fold greater amount in normal SI compared to normal cerebellum.

\section{CONCLUSION}

There is evidence now available for alterations of normal gene expression in $\mathrm{AD}$ affected brains. How these changes may lead to the neuronal degeneration and formation of amyloid containing neuritic plaques and neurofibrillary tangles can still only be the subject of speculation and a considerable amount of further investigation. Strategies for the identification of genes, from an SI cDNA library, that are differentially expressed in different brain regions and whose expression is altered in $A D$ affected brains, have been developed. These strategies have led to the identification of anonymous genes that have been characterized on the basis of their expression in different brain regions. There is now available a range of scientific techniques that can be used to identify the proteins these genes code for and in which type of cells they occur. It is now possible to obtain the DNA sequence, identify the proteins these genes code for, and prepare synthetic peptide segments of these proteins. These peptides can be used to produce antibodies, which can be used to identify and isolate the proteins from brain tissue. With these techniques, new approaches for research in $\mathrm{AD}$ are now open.

\section{ACKNOWLEDGEMENTS}

This work was supported by grants from the Alzheimer Disease and Related Disorders Association, Medical Research Council of Canada and Alzheimer Society of British Columbia. DGW is a research fellow of the Alzheimer Society of British Columbia.

\section{REFERENCES}

1. Selkoe DJ. Biochemistry of altered brain proteins in Alzheimer's disease. Ann Rev Neurosci 1988; 12: 463-490.

2. McGeer PL, McGeer EG, Suzuki J, et al. Aging, Alzheimer's Disease, and the cholinergic system of the basal forebrain. Neurology 1984; 34: 741-745.

3. Price DL, Koo EH, Muma NA, et al. Alzheimer's disease and Animal models: Correlations of behavioural and brain abnormalities. In: Henderson AS, Henderson JH, eds. Etiology of Dementia of Alzheimer's type. Chichester: Wiley, 1988: 65-82.

4. Langstrom NS, Anderson JP, Lindros HG, et al. Alzheimer's disease-associated reduction of polysomal mRNA translation. Mol Brain Res 1989; 5: 259-270.

5. Glenner GC, Wong CW. Alzheimer's disease: Initial report of the purification and characterization of a novel cerebrovascular amyloid protein. Biochem Biophys Res Comm 1984; 120: 885890.

6. Kang J, Lemaire HG, Unterbeck A, et al. The precursor of Alzheimer's disease amyloid A4 protein resembles a cell-surface receptor. Nature 1987; 325: 733-736.

7. Tanzi RE, Gusella JF, Watkins PL, et al. Amyloid B protein gene: cDNA, mRNA distribution, and genetic linkage near the Alzheimer locus. Science 1987; 235: 880-884.

8. Robakis NK, Ramakrishna N, Wolfe G, et al. Molecular cloning and characterization of a cDNA encoding the cerebrovascular and neuritic plaque amyloid peptides. Proc Natl Acad Sci USA 1987; 84: 4190-4194.

9. Goldgaber D, Lerman MI, McBride OW, et al. Characterization and chromosomal localization of a cDNA encoding brain amyloid of Alzheimer's disease. Science; 1987: 877-880.

10. Shivers BD, Hilbich C, Multhaup G, et al. Alzheimer's disease amyloidogenic glycoprotein: Expression pattern in rat brain suggests a role in cell contact. EMBO J 1988; 7: 1365-1370.
11. Manning RW, Reid CM, Lampe RA, et al. Identification in rodents and other species of an mRNA homologous to the human B-amyloid precursor. Mol Brain Res 1988; 3: 293-298.

12. Ponte $P$, Gonzales-DeWhitt $P$, Schillling J, et al. A new A4 amyloid mRNA contains a domain homologous to serine proteinase inhibitors. Nature 1988; 331: 525-527.

13. Tanzi RE, McClatchey AI, Lamperti ED, et al. Protease inhibitor domain encoded by an amyloid protein precursor mRNA associated with Alzheimer's disease. Nature 1988; 331: 528-530.

14. Kitaguchi N, Takahashi Y, Tokushima Y, et al. Novel precursor of Alzheimer's disease amyloid protein shows protease inhibitory activity. Nature 1988; 331; 530-532.

15. Goedert M. Neuronal localization of amyloid beta protein precursor mRNA in normal human brain and in Alzheimer's disease. EMBO J 1987; 6: 3627-3632.

16. Clark AW, Kerkoski CA, Parhad IM, et al. Altered expression of genes for amyloid and cytoskeletal proteins in Alzheimer cortex. Ann Neurol 1989; 25: 331-339.

17. Tanaka $S$, Nakamura $S$, Ueda $K$, et al. Three types of amyloid protein precursor mRNA in human brain: their differential expression in Alzheimer's disease. Biochem Biophys Res Comm 1988; 2: $472-479$.

18. Johnson SA, Pasinetti GM, May PC, et al. Selective reduction of mRNA for the beta-amyloid precursor protein that lacks a Kunitz-type protease inhibitor motif in cortex from Alzheimer brains. Exp Neurol 1988; 102: 264-268.

19. Cohen ML, Golde TE, Usiak MF, et al. In situ hybridization of nucleus basalis neurons shows increased $B$ amyloid mRNA in Alzheimer disease. Proc Natl Acad Sci USA 1988; 85: 1227-1221.

20. Palmert MR, Golde TE, Cohen ML, et al. Amyloid protein precursor messenger RNAs: Differential expression in Alzheimer's disease. Science 1988; 241: 1080-1084.

21. Higgins GA, Lewis DA, Bahmanyar S, et al. Differential regulation of amyloid-protein mRNA expression within hippocampal neuronal subpopulations in Alzheimer disease. Proc Natl Acad Sci USA 1988; 85: 1297-1301.

22. Vitek MP, Rasool CG, de Sauvage F, et al. Absence of mutation in the $B$-amyloid cDNAs cloned from the brains of three patients with sporadic Alzheimer's disease. Mol Brain Res 1988; 4: 121131.

23. St George-Hyslop PH, Tanzi RE, Polinsky RJ, et al. The genetic defect causing Alzheimer's disease maps on chromosome 21. Science 1987; 235: 885-889.

24. Tanzi RE, St George-Hyslop PH, Haines JL, et al. The genetic defect in familial Alzheimer's disease is not tightly linked to the amyloid beta protein gene. Nature 1987; 329: 156-157.

25. Tanzi RE, Bird ED, Latt SA, et al. The amyloid $B$ protein gene is not duplicated in brains from patients with Alzheimer's disease. Science 1987; 238: 666-669.

26. Goedert M, Wischik CM, Crowther RA, et al. Cloning and sequencing of the cDNA encoding a core protein of the paired helical filament of Alzheimer disease: Identification as the microtubule-associated protein tau. Proc Natl Acad Sci USA 1988; 85: 4051-4055.

27. Crapper McLachlan DR, Lukiw WJ, Wong L, et al. Selective messenger RNA reduction in Alzheimer's disease. Mol Brain Res 1988; 3: 255-262.

28. Zain SB, Salim M, Chou W-G, et al. Molecular cloning of amyloid cDNA derived from mRNA of the Alzheimer brain: Coding and non-coding regions of the fetal precursor mRNA are expressed in the Alzheimer cortex. Proc Natl Acad Sci USA 1988; 85: 929 933.

29. Goedert M, Fine A, Hunt SP, et al. Nerve growth factor mRNA in peripheral and central rat tissues and in the human central nervous system: Lesion effects in the rat brain and levels in Alzheimer's disease. Mol Brain Res 1986; 1: 85-92.

30. Whittemore SR, Ebendal T, Larkfors L, et al. Developmental and regional expression of $B$ nerve growth factor messenger RNA and protein in the rat central nervous system. Proc Natl Acad Sci USA 1986; 83: 817-821. 
31. Hefti F. Nerve growth factor promotes survival of septal cholinergic neurons after fimbrial transections. J Neurosci 1986; 8: $2155-$ 2162.

32. Goedert M, Fine A, Dawbam D, et al. Nerve growth factor receptor mRNA distribution in human brain: normal levels in basal forebrain in Alzheimer's disease. Mol Brain Res 1988; 5: 1-7.

33. Whitehouse PJ, Price DL, Struble RG, et al. Alzheimer's disease and senile dementia: loss of neurons in the basal forebrain. Science 1982; 215: 1237-1239.

34. Etienne P, Robitaille Y, Wood P, et al. Nucleus basalis neuronal loss, neuritic plaques and choline acetyltransferase activity in advanced Alzheimer's disease. Neuroscience 1986; 19: 12791291.

35. Sutcliffe JG. mRNA in the mammalian central nervous system. Ann Rev Neurosci 1988; 11: 157-198.

36. Miller FD, Naus CCG, Higgins GA, et al. Developmentally regulated rat brain mRNAs: Molecular and anatomical characterization. J Neurosci 1987; 7: 2433-2444.

37. Nordquist DT, Kozak CA, Orr HT. cDNA cloning and characterization of three genes uniquely expressed in cerebellum by Purkinje neurons. J Neurosci 1988; 8: 4780-4789.

38. Duguid JR, Rohwer RG, Seed B. Isolation of cDNAs of scrapiemodulated RNAs by subtractive hybridization of a cDNA library. Proc Natl Acad Sci USA 1988; 85: 5738-5742.

39. May PC, Johnson SA, Lampert-Etchells ME, In situ mapping of pADHC-9: A poly A RNA sequence overexpressed in
Alzheimer's disease hippocampus. Soc Neurosci Abstr 1988; 14: 897 .

40. Chirgwin JM, Pryzbala AE, MacDonald RJ, et al. Isolation of biologically active ribonucleic acid from sources enriched in ribonuclease. Biochemistry 1979; 18: 5294-5299.

41. Gubler U, Hoffman BJ. A simple and very efficient method of generating cDNA libraries. Gene 1983; 25: 263-269.

42. Dower WJ, Miller JF, Ragsdale CW. High efficiency transformation of E.coli by high voltage electroporation. Nuc Acid Res 1988; 13: 6127-6145.

43. Schmid DW, Girou C. Cloning of cDNA derived from mRNA of the electric lobe of Torpedo marmorata and selection of putative cholinergic-specific sequences. J Neurochem 1987; 48: 307-312.

44. Dworkin MB, Dawid IB. Use of a cloned library for the study of abundant poly (A)+ RNA during Xenopus laevis development. Dev Biol 1980; 76: 449-464.

45. Hedreen JC, Struble RG, Whitehouse PJ, et al. Topography of the magnocellular basal forebrain system in human brain. J Exp Neurol Neuropath 1984; 43: 1-21.

46. Travis GH, Naus CG, Bloom FE, et al. Subtractive cDNA cloning and analysis of primate neocortex mRNAs with regionally heterogeneous distributions. Neuropharmacology 1987; 25: 845854 .

47. Lee JJ, Costlow NA. A molecular titration assay to measure transcript prevalence. In: Berger SL, Kimmel AR, eds. Methods in Enzymology. Orlando: Academic Press, 1987; 152: 633-648. 